\title{
Respiratory management of the preterm newborn in the delivery room
}

\author{
This article was published in the following Dove Press journal: \\ Research and Reports in Neonatology \\ 26 May 2012 \\ Number of times this article has been viewed
}

\author{
Hesham Abdel-Hady \\ Nehad Nasef \\ Neonatal Intensive Care Unit, \\ Mansoura University Children's \\ Hospital, Mansoura, Egypt
}

Correspondence: Hesham Abdel-Hady Neonatal Intensive Care Unit, Mansoura University Children's Hospital, Gomhoria Street, Mansoura 35516, Egypt

$\mathrm{Tel}+2000527805 \mathrm{I}$

$\mathrm{Fax}+20502234092$

Email hehady@yahoo.com

\begin{abstract}
The survival of preterm infants has improved significantly during the past several decades. However, bronchopulmonary dysplasia remains a major morbidity. Preterm infants have both structural and functional lung immaturity compared with term infants, making them more likely to require resuscitation and more vulnerable to developing bronchopulmonary dysplasia. Interventions in the delivery room may affect short-term and long-term outcomes for preterm infants. The paradigm of resuscitation of preterm infants has been changing over the past decade from being interventional and invasive to be observational and gentle. Recent developments in respiratory management of preterm infants in the delivery room include oxygen supplementation and monitoring, alveolar recruitment techniques, noninvasive ventilation, new surfactant preparations, and new techniques for administration of surfactant. Providing nasal continuous positive airway pressure (CPAP) rather than intubating has been identified as a potentially better practice. Experimental studies have demonstrated that early application of nasal CPAP is protective for the preterm lung and brain compared with mechanical ventilation. Several observational studies have suggested that early nasal CPAP and avoiding intubation leads to reduced oxygen requirements, intubation rates, duration of mechanical ventilation, and may decrease rates of bronchopulmonary dysplasia. Multicenter, randomized controlled trials support the use of nasal CPAP as a primary strategy in preterm babies with respiratory distress syndrome. This approach leads to a reduction in the number of infants who are intubated and given surfactant without an impact on bronchopulmonary dysplasia rates. On the other hand, half of the infants enrolled in these studies failed nasal CPAP treatment. New techniques for surfactant administration include INSURE ("intubate give surfactant and extubate"), administration through a laryngeal mask airway, nebulized surfactant administration, and minimally invasive surfactant therapy.
\end{abstract}

Keywords: continuous positive airway pressure, lung injury, oxygen, resuscitation, surfactants

\section{Introduction}

Preterm infants are at increased risk of morbidity and mortality because of the immaturity of all their body systems, especially the lungs. Survival of preterm infants has improved over the past several decades, mainly due to new interventions, such as use of prenatal corticosteroids, surfactant replacement therapy, and new modalities of mechanical ventilation. ${ }^{1-4}$ This improvement in mortality has not been paralleled by a decrease in morbidity. The prevalence of complications, such as bronchopulmonary dysplasia, retinopathy of prematurity, severe intraventricular hemorrhage, and periventricular leukomalacia have not changed substantially. ${ }^{4-6}$ Moreover, these infants continue to be at risk of adverse neurodevelopmental sequelae. ${ }^{7}$ Delivery room practices during the 
first minutes of life have a great potential to improve these outcomes. The concept of a delivery room intensive care unit has recently been introduced, emphasizing the need to improve the technical equipment at the delivery room bed "as if it were a neonatal intensive care unit (NICU) bed". ${ }^{8}$

\section{Physiology}

Respiratory management of preterm infants in the delivery room represents a great challenge for neonatologists because preterm infants are more likely to need significant resuscitation effort and are more likely to develop complications related to this effort. ${ }^{9}$ Accordingly, understanding the physiological differences between the lungs of preterm infants and term infants is important to be able to provide effective and safe resuscitation. Preterm infants have both structural and functional lung immaturity compared with term infants. Intrauterine lung maturation has been divided into five phases, ie, embryonic (26 days to 6 weeks' gestation), pseudoglandular (6-16 weeks' gestation), acinar or canalicular (16-28 weeks' gestation), saccular (28-34 weeks' gestation), and alveolar (36 weeks' gestation until 18 postnatal months). ${ }^{10}$ Thus, preterm infants delivered at 23-34 weeks' gestation during the acinar, canalicular, and saccular stages of development appear to be most susceptible to lung injury. ${ }^{10,11}$ At these stages, the premature lung has poorly developed supporting structures in the airway and a smaller alveolar surface area.

Together with structural lung immaturity, preterm infants have both quantitative and qualitative immaturity of surfactant. Surfactant from immature lungs contains larger amounts of phosphatidylinositol, smaller amounts of phosphatidylglycerol, and has a lower protein to lipid ratio compared with surfactant from mature lungs. ${ }^{12}$ Due to its lower content of phosphatidylglycerol, surfactant from premature lungs has lower surface activity. The phosphatidylglycerol content of surfactant begins to rise after 35 weeks' gestation. Surfactant proteins are expressed at varying degrees at different stages of gestation, with surfactant protein A after 32 weeks' gestation, surfactant protein B after 34 weeks' gestation, surfactant protein C during early lung development, and surfactant protein D at late gestation. Owing to structural and functional immaturity, the lungs of preterm infants are more vulnerable to barotrauma, volutrauma, atelectrauma, and biotrauma.

Immature antioxidant defense systems increase the susceptibility of preterm infants to oxidative stress and concomitant morbidities of prematurity, including bronchopulmonary dysplasia, retinopathy of prematurity, and necrotizing enterocolitis. ${ }^{13}$ Thus, the use of excess supplemental oxygen for resuscitation of preterm infants in the delivery room may be injurious. Hypothermia, perinatal infection, immaturity of respiratory drive, and weak respiratory muscles are cofactors that further add to the unique features of preterm infants and contribute to the need for neonatal resuscitation.

\section{Resuscitation}

Unlike for full term infants, there is no clear and approved consensus among neonatologists regarding delivery room resuscitation and respiratory management of preterm infants. The paradigm of resuscitation of preterm infants has been changing over the past decade from being interventional and invasive to be observational and gentle. This change is attributed to the accumulating evidence that early, even if brief, positive pressure ventilation, large tidal volume, and oxygen therapy initiate a process of inflammation, remodeling, and injury in premature lungs. ${ }^{14}$ Recent developments in respiratory management of preterm infants in the delivery room include limitation of excess oxygen use in resuscitation, limitation of inflating pressure, use of a T-piece resuscitator, recognition of the value of a sustained lung inflation technique, early use of noninvasive ventilation, and the INSURE ("intubate give surfactant and extubate") method for surfactant administration.

\section{Oxygen therapy and target oxygen saturation}

Over the past few years, evidence has been growing to indicate that routine use of $100 \%$ oxygen for neonatal resuscitation is not superior to room air and may be hazardous to newborn infants. ${ }^{15,16}$ Although preterm infants are more susceptible to hyperoxia and oxidative stress with use of pure oxygen, the data suggest that room air may be insufficient to achieve target oxygen levels. ${ }^{17}$ In an observational study of resuscitating preterm infants $<30$ weeks' gestation with room air, $95 \%$ of the enrolled infants failed to achieve target oxygen saturation by five minutes of age and required supplemental oxygen. ${ }^{18}$ In two trials, preterm infants $<28$ weeks' gestation were randomly assigned to receive $30 \%$ with a step-up increment versus $90 \%$ oxygen with a step-down decrement during initial resuscitation, and no differences were found in mortality or pulse oximetry percent saturation $\left(\mathrm{SpO}_{2}\right)$ values from 1-20 minutes of life, but those resuscitated with $30 \%$ oxygen needed fewer days of oxygen supplementation and mechanical ventilation, and had a lower incidence of bronchopulmonary dysplasia. ${ }^{19,20}$ Although the updated 
American Heart Association guidelines recommended initial resuscitation of preterm infants with blended oxygen without specification, ${ }^{21}$ it seems reasonable to start at a concentration of $30 \%$ and step up gradually according to response.

The target $\mathrm{SpO}_{2}$ range that adequately meets metabolic demands and limits oxygen toxicity for the preterm infants has garnered the interest of investigators over the past decade. Four major trials have investigated target $\mathrm{SpO}_{2}$ in preterm infants (Table 1), ${ }^{22-25}$ but only one of these studies enrolled infants in the delivery room. Three levels of saturation were thoroughly evaluated in these trials, including low targeted saturation at $85 \%-90 \%$, medium targeted saturation at 91\%-95\%, and high targeted saturation at 95\%-99\%. Data from the individual trials suggest that high targeted saturation over $95 \%$ was associated with bronchopulmonary dysplasia and oxygen dependency. Pooled data from premature infants $<28$ weeks from SUPPORT (the Surfactant, Positive Pressure, and Pulse Oximetry Randomized Trial) and the BOOST (Benefits of Oxygen Saturation Targeting) II trial showed a higher survival rate in infants assigned to a target oxygen saturation of $91 \%-95 \%$ compared with the low saturation of $85 \%-89 \% .{ }^{24}$ Recently, nomograms for oxygen saturation and heart rate in the first minutes of life for preterm babies have been developed, showing a slow rise in oxygen saturation after birth. ${ }^{26,27} \mathrm{SpO}_{2}$ values within the 90th and 10th centile could be considered a valid reference for assessing improvement and need for oxygen administration. ${ }^{28}$

\section{Appropriate inflating pressure of the lungs}

There is no consensus about the inflating pressure needed to resuscitate preterm infants. Experimental studies have suggested that lungs are injured if they are inflated with either a high pressure to volumes that exceed total lung capacity, or low pressures to small volumes below a normal functional residual capacity. ${ }^{29}$ Overdistension of the lung (volutrauma) and insufficient lung volumes (atelectrauma) can initiate an inflammatory process, which may progress to bronchopulmonary dysplasia. ${ }^{30,31}$ Bjorklund et al showed in preterm lambs that as few as six large insufflations with tidal volumes of $35-40 \mathrm{~mL} / \mathrm{kg}$, probably harmless in normal circumstances, forced into a surfactant-deficient lung immediately after birth can compromise the effect of subsequent surfactant rescue treatment. The immature lambs were more difficult to ventilate and had more widespread lung injury in histological sections. ${ }^{32}$ Hoskyns et al reported that

Table I Studies addressing target oxygen saturation in preterm infants

\begin{tabular}{|c|c|c|c|c|}
\hline Study & Population & Comparison & Primary outcome & Main results \\
\hline STOP-ROP ${ }^{22}$ & $\begin{array}{l}649 \text { preterm infants } \\
\pm 25.4 \text { weeks' gestation }\end{array}$ & $\begin{array}{l}\text { High } \mathrm{SpO}_{2}(96 \%-99 \%) \\
\text { versus low } \mathrm{SpO}_{2}(89 \%-94 \%)\end{array}$ & $\begin{array}{l}\text { Progression to threshold } \\
\text { retinopathy of prematurity } \\
\text { and need for peripheral } \\
\text { retinal ablation }\end{array}$ & 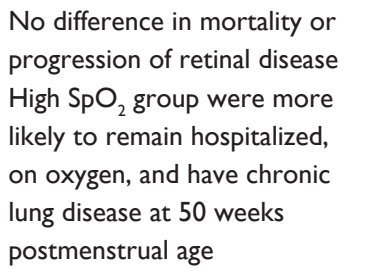 \\
\hline BOOST- $\left.\right|^{23}$ & $\begin{array}{l}358 \text { preterm infants } \\
<30 \text { weeks' gestation }\end{array}$ & $\begin{array}{l}\text { High } \mathrm{SpO}_{2}(95 \%-98 \%) \\
\text { versus } \\
\text { low } \mathrm{SpO}_{2}(91 \%-94 \%)\end{array}$ & $\begin{array}{l}\text { Growth and neurodevelopmental } \\
\text { measures at a corrected age of } \\
\text { I } 2 \text { months }\end{array}$ & $\begin{array}{l}\text { No difference in } \\
\text { neurodevelopmental outcome } \\
\text { Six infants died of pulmonary } \\
\text { cause in the high } \mathrm{SpO}_{2} \text { group } \\
\text { High } \mathrm{SpO}_{2} \text { group received } \\
\text { longer oxygen therapy, and } \\
\text { were more likely to receive } \\
\text { supplemental oxygen at } 36 \text { weeks } \\
\text { postmenstrual age and at home }\end{array}$ \\
\hline BOOST-II24 & $\begin{array}{l}\text { I } 200 \text { preterm infants } \\
<28 \text { weeks' gestation }\end{array}$ & $\begin{array}{l}\text { High } \mathrm{SpO}_{2}(91 \%-95 \%) \\
\text { versus } \\
\text { low } \mathrm{SpO}_{2}(85 \%-89 \%)\end{array}$ & $\begin{array}{l}\text { Survival without disability at } \\
2 \text { years corrected for gestation }\end{array}$ & $\begin{array}{l}\text { The study was closed early after } \\
\text { a safety analysis demonstrated a } \\
\text { higher survival rate in the group } \\
\text { that was randomly assigned to a } \\
\text { high target } \mathrm{SpO}_{2}\end{array}$ \\
\hline SUPPORT $^{25}$ & $\begin{array}{l}1316 \text { preterm infants } \\
\pm 26 \text { weeks' gestation }\end{array}$ & $\begin{array}{l}\text { High } \mathrm{SpO}_{2}(91 \%-95 \%) \\
\text { versus } \\
\text { low } \mathrm{SpO}_{2}(85 \%-89 \%)\end{array}$ & $\begin{array}{l}\text { Composite of severe retinopathy } \\
\text { of prematurity, death before } \\
\text { discharge from the hospital, } \\
\text { or both }\end{array}$ & $\begin{array}{l}\text { Low target saturation group } \\
\text { were less likely to have severe } \\
\text { ROP but had a higher mortality } \\
\text { rate before discharge }\end{array}$ \\
\hline
\end{tabular}

Abbreviations: STOP-ROP, Supplemental Therapeutic Oxygen for Prethreshold Retinopathy of Prematurity; BOOST, Benefits of Oxygen Saturation Targeting; SUPPORT, Surfactant, positive pressure, and pulse oximetry randomized; $\mathrm{SpO}_{2}$, pulse oximetry percent saturation. 
inflation pressures of 25-30 $\mathrm{cm} \mathrm{H}_{2} \mathrm{O}$ in preterm infants rarely led to tidal volumes of more than $4 \mathrm{~mL} / \mathrm{kg}$, although higher pressures were sometimes needed for optimal resuscitation. ${ }^{33}$ In contrast, Hird et al found that a median inflation pressure of $22.8 \mathrm{~cm} \mathrm{H}_{2} \mathrm{O}$ was necessary to generate adequate chest wall expansion in preterm infants, with no infant requiring a peak inspiratory pressure $>30 \mathrm{~cm} \mathrm{H_{2 }}$ O. ${ }^{34}$ Assessment of chest rise as a measure of lung expansion is not very accurate and might lead to delivery of excessive tidal volumes. ${ }^{35}$ Thus, monitoring of respiratory function has recently been suggested as a useful tool during resuscitation of preterm infants to minimize lung barotrauma and volutrauma. ${ }^{36}$

\section{Use of a T-piece resuscitator}

The T-piece resuscitator (Neopuff ${ }^{\circledR}$ ) is similar to the flowinflating bag in providing positive end-expiratory pressure, but with the addition of an adjustable flow control valve. The flow control valve allows for more precise control of the peak inspiratory pressure applied to the infant's lung, decreases the risk of lung barotrauma, and enables application of prolonged initial inflation breaths and positive end-expiratory pressure to be maintained between inflations, and can give continuous positive airway pressure (CPAP) when it is not being used as a ventilator. The T-piece resuscitator was found more consistently to deliver target pressures and prolonged inflation independent of the operator's expertise compared with manual bagging devices. ${ }^{37}$ In a qualitative review of 30 trials comparing the T-piece resuscitator with self-inflating bags, two on infants and 28 on manikins, no superiority was found for the T-piece resuscitator over the self-inflating bag in the infant trials, but in the manikin studies the T-piece resuscitator was able to deliver inflating pressures closer to predetermined target pressures with minimal variation and to provide prolonged inflation breaths and more consistent tidal volumes. ${ }^{38}$ Currently, target ventilation variables with the T-piece resuscitator include a respiratory rate of 40 breaths per minute, a peak inspiratory pressure of $20 \mathrm{~cm} \mathrm{H}_{2} \mathrm{O}$, and a positive end-expiratory pressure of $4 \mathrm{~cm} \mathrm{H}_{2} \mathrm{O} \cdot{ }^{39}$

\section{Value of sustained lung inflation technique}

The first breaths in a full term newborn have a prolonged expiratory phase associated with a high positive intrathoracic pressure, and a brief inspiratory component to facilitate the distribution of air within the lungs and to assist in formation of the functional residual capacity. ${ }^{40}$ In an experimental study, it was found that sustained inflation of preterm rabbit lungs for durations of 10 or 20 seconds increased the inspiratory volume and produced a greater functional residual capacity compared with durations of one or 5 seconds. ${ }^{41}$ Sustained lung inflation for 20 seconds in combination with positive end-expiratory pressure was found to improve the functional residual capacity of preterm rabbit pups. ${ }^{42}$ In asphyxiated full term infants, sustained lung inflation during resuscitation was found to increase their tidal volume and the functional residual capacity. ${ }^{43}$ The European Resuscitation Council has recommended that initial inflation of the lung should be 2-3 seconds in duration to achieve a sustained lung inflation technique. ${ }^{44,45}$ In preterm infants, sustained lung inflation for 5 seconds compared with traditional lung inflation for 2 seconds did not reduce lung injury, as measured by inflammatory cytokines. ${ }^{46}$ Lindner et al compared sustained lung inflation with nasal intermittent positive pressure ventilation (IPPV) for treatment of preterm infants with respiratory distress syndrome in the delivery room, and found no significant difference in the need for mechanical ventilation or rate of adverse effects. ${ }^{47}$ te Pas and Walther found a decrease in need for intubation and bronchopulmonary dysplasia in preterm infants of more than 28 weeks' gestation treated by sustained lung inflation at a pressure of $20 \mathrm{~cm} \mathrm{H}_{2} \mathrm{O}$ for 10 seconds using a T-piece resuscitator compared with a self-inflating bag and mask in the delivery room. ${ }^{48}$ In preterm infants with respiratory distress syndrome, sustained lung inflation at a pressure of $25 \mathrm{~cm} \mathrm{H_{2 }} \mathrm{O}$ for 15 seconds using a T-piece resuscitator was found to decrease the need for mechanical ventilation compared with using a T-piece resuscitator without sustained lung inflation, without inducing evident adverse effects. ${ }^{49}$ However, issues like appropriate duration and pressure, hemodynamic changes, and risk of barotrauma, should be further evaluated before recommending routine use of sustained lung inflation in the resuscitation of preterm infants.

\section{Continuous positive airway pressure Mechanism of action}

CPAP is a technique of respiratory support that generates a continuous distending pressure to the lung and is delivered to spontaneously breathing infants. Usually, a pressure of $4-8 \mathrm{~cm} \mathrm{H}_{2} \mathrm{O}$ is used to distend the airways and alveoli. CPAP improves oxygenation without increasing peripheral arterial carbon dioxide tension $\left(\mathrm{PaCO}_{2}\right)$ through stabilization and recruitment of collapsed alveoli. The functional residual capacity is increased, resulting in an increased alveolar surface area for gas exchange and a decrease in intrapulmonary shunting. CPAP enhances the release of surfactant and helps maintain the surfactant present on the alveolar surface. It stabilizes the chest wall and dilates 
the airways, reduces inspiratory resistance, increases lung compliance, counteracts paradoxical movement, and reduces thoracoabdominal asynchrony of the chest wall and reduces the work of breathing. ${ }^{50,51}$

\section{Evidence for early use of CPAP in preterm infants}

CPAP was first used as a method of supporting breathing in preterm infants in $1971 .^{52}$ Even after the introduction of surfactant replacement therapy and new mechanical ventilation strategies in the management of respiratory distress syndrome, bronchopulmonary dysplasia remained a frequent sequel of prematurity, and mechanical ventilation was described as the important predisposing factor for bronchopulmonary dysplasia; thus, by avoiding intubation and mechanical ventilation, many of these infants will not develop bronchopulmonary dysplasia. ${ }^{53}$ Today, there is increased interest in the use of nasal CPAP in extremely low birth-weight (ELBW) and very low birth-weight (VLBW) infants, ${ }^{54}$ and providing nasal CPAP rather than intubation has been identified as a potentially better practice according to basic quality improvement criteria. ${ }^{55,56}$ The evidence for early application of nasal CPAP in this population comes from experimental, observational/retrospective, and randomized controlled trials.

\section{Experimental studies}

Experimental studies demonstrated that early application of CPAP is protective for the preterm lung and brain compared with mechanical ventilation. The ventilatory strategy of "open up the lung and keep it open" will minimize lung damage, therefore starting nasal CPAP directly after resuscitation is a gentle, noninvasive attempt to keep the lung open. ${ }^{57}$ Jobe et al showed in preterm lambs that nasal CPAP after birth results in lower indicators of acute lung injury than conventional mechanical ventilation during the first 2 hours of life. ${ }^{58}$ More recently, the same research group randomized preterm lambs to bubble CPAP ( 5 or $8 \mathrm{~cm} \mathrm{H}_{2} \mathrm{O}$ ) or conventional mechanical ventilation for a period of 2-6 hours. They demonstrated larger lung volumes and better oxygenation with CPAP $8 \mathrm{~cm} \mathrm{H}_{2} \mathrm{O}$ compared with CPAP $5 \mathrm{~cm} \mathrm{H}_{2} \mathrm{O}$, and lung dry/wet ratios were greater for both CPAP groups than for the mechanical ventilation group. Lambs that demonstrated terminal respiratory failure on CPAP within 2 hours had smaller surfactant pools (supporting early administration of surfactant to the most immature infants who are likely to be surfactant-deficient). ${ }^{59}$ The value of surfactant replacement therapy coupled with CPAP has been demonstrated in another study showing that animals treated with surfactant prior to CPAP had less acute lung injury, suggesting that surfactant administration may modulate pulmonary inflammation and that CPAP alone without surfactant may not provide optimal pulmonary protection. ${ }^{60}$ The lungs of premature baboons maintained on CPAP for 28 days demonstrated thin-walled airspaces with minimal fibroproliferation and scattered secondary crests. Pressure-volume curves were nearly identical to those observed at term gestation, but significantly better than those from preterm baboons ventilated with low tidal volume ("gentle") positive pressure ventilation. ${ }^{61}$ In contrast with these findings, another study ${ }^{62}$ demonstrated comparable acute effects on lung and systemic inflammation of CPAP $\left(8 \mathrm{~cm} \mathrm{H}_{2} \mathrm{O}\right)$ and gentle conventional mechanical ventilation (tidal volume $8 \mathrm{~mL} / \mathrm{kg}$ ), leading to the conclusion that CPAP given shortly after birth fails to attenuate lung injury, supporting the results of randomized controlled trials of early use of CPAP where no reduction of bronchopulmonary dysplasia in preterm infants was observed. ${ }^{63-66}$ Early CPAP was associated with less cerebral injury, ${ }^{67}$ higher cerebellar weight, ${ }^{68}$ and less damage to specific classes of neurons in the visual cortex expressing gamma aminobutyric acid ${ }^{69}$ compared with delayed CPAP preceded by positive pressure ventilation in premature baboons.

\section{Observational/retrospective studies}

Several observational/retrospective studies have evaluated early use of CPAP in preterm infants ${ }^{70-83}$ (Table 2), with most of these studies suggesting that early use of nasal CPAP and avoiding intubation leads to reduced oxygen requirements, intubation rates, and duration of mechanical ventilation, and some studies reporting decreased rates of bronchopulmonary dysplasia. ${ }^{72,73,75,76,79,80,83}$ Other observational studies compared the rates of bronchopulmonary dysplasia in centers using early nasal CPAP with centers preferring intubation and mechanical ventilation. The pioneering work of Avery et $\mathrm{al}^{84}$ found that NICUs using less intubation and mechanical ventilation reported less bronchopulmonary dysplasia compared with other NICUs. Van Marter et $\mathrm{al}^{53}$ observed marked differences in the incidence of bronchopulmonary dysplasia (4\% at the Babies Hospital, Columbia University, versus $22 \%$ at two Boston hospitals) despite similar mortality rates. Infants at the Babies Hospital were less likely to be mechanically ventilated, and those who did were ventilated for significantly shorter time periods. In multivariate logistic regression analyses, initiation of mechanical ventilation was associated with an increased risk of bronchopulmonary dysplasia. ${ }^{53}$ Another study showed 
Table 2 Studies evaluating respiratory outcomes after application of early nasal CPAP in preterm infants

\begin{tabular}{|c|c|}
\hline Reference & Main results \\
\hline Jacobsen et $\mathrm{al}^{70}$ & $\begin{array}{l}\text { Decreased need for mechanical ventilation } \\
\text { (from } 76 \% \text { to } 35 \% \text { ) } \\
\text { Decreased IVH grade II-IV } \\
\text { No difference in rate of death or BPD }\end{array}$ \\
\hline Gittermann et $\mathrm{a}^{71}$ & $\begin{array}{l}\text { Decreased need for mechanical ventilation } \\
\text { (from } 53 \% \text { to } 30 \% \text { ) } \\
\text { No difference in rate of death or BPD }\end{array}$ \\
\hline Lindner et $\mathrm{al}^{72}$ & $\begin{array}{l}\text { Decreased need for mechanical ventilation } \\
\text { (from } 25 \% \text { to } 7 \% \text { ) } \\
\text { Decreased rate of BPD and IVH, } \\
\text { and shorter hospital stays } \\
\text { No difference in mortality }\end{array}$ \\
\hline $\begin{array}{l}\text { De Klerk and } \\
\text { De Klerk }{ }^{73}\end{array}$ & $\begin{array}{l}\text { Decreased need for mechanical ventilation } \\
\text { (from } 65 \% \text { to } 14 \% \text { ) } \\
\text { Decreased surfactant use, durations of } \\
\text { ventilation and of oxygen therapy } \\
\text { Decreased rate of death or BPD } \\
\text { (from } 16 \% \text { to } 3 \% \text { ) }\end{array}$ \\
\hline Narendran et $\mathrm{a}^{74}$ & $\begin{array}{l}\text { Decreased need for intubation in the delivery } \\
\text { room }(60 \% \text { versus } 32 \%) \\
\text { Shorter duration of mechanical ventilation } \\
\text { No difference in rate of death or BPD }\end{array}$ \\
\hline Aly et $\mathrm{al}^{75,76}$ & $\begin{array}{l}\text { Decreased rate of death or BPD } \\
\text { (from } 65 \% \text { to } 27 \% \text { ) } \\
\text { Over time, the incidence of BPD decreased } \\
\text { significantly (from } 33 \% \text { to II\%) and average } \\
\text { weight gain increased }\end{array}$ \\
\hline Jegatheesan et $\mathrm{al}^{77}$ & $\begin{array}{l}\text { Shorter durations of mechanical ventilation } \\
\text { and supplemental oxygen } \\
\text { No difference in rate of death or BPD }\end{array}$ \\
\hline Zecca et $\mathrm{al}^{78}$ & $\begin{array}{l}\text { No difference in duration of supplemental } \\
\text { oxygen } \\
\text { No difference in rate of death or BPD }\end{array}$ \\
\hline Geary et $\mathrm{al}^{79}$ & $\begin{array}{l}\text { Decreased need for mechanical ventilation } \\
\text { (from } 99 \% \text { to } 60 \% \text { ) } \\
\text { Shorter durations of mechanical ventilation } \\
\text { and oxygen therapy } \\
\text { Decreased the rate of moderate and severe } \\
\text { BPD (from } 43 \% \text { to } 24 \% \text { ) }\end{array}$ \\
\hline Miksch et al ${ }^{80}$ & $\begin{array}{l}\text { Decreased intubation (from } 81 \% \text { to } 58 \% \text { ) } \\
\text { Shorter durations of oxygen therapy } \\
\text { Decreased incidence of BPD (from } 55 \% \text { to } 18 \% \text { ) } \\
\text { for all surviving infants, and for ELBW infants } \\
\text { (from } 90 \% \text { to } 30 \% \text { ) }\end{array}$ \\
\hline te Pas et $\mathrm{al}^{81}$ & $\begin{array}{l}\text { Decreased the need for intubation within } \\
72 \text { hours of age } \\
\text { No difference in rate of death or BPD }\end{array}$ \\
\hline Nowadzky et a ${ }^{82}$ & $\begin{array}{l}\text { Decreased the use of mechanical ventilation } \\
\text { and its duration } \\
\text { No difference in rate of death or BPD }\end{array}$ \\
\hline Mulder et $\mathrm{a}^{83}$ & $\begin{array}{l}\text { Decreased the rate of BPD } \\
\text { (from } 47 \% \text { to } 37 \% \text { ) } \\
\text { No difference in mortality }\end{array}$ \\
\hline
\end{tabular}

Abbreviations: NCPAP, nasal continuous positive airway pressure; BPD, bronchopulmonary dysplasia; IVH, intraventricular hemorrhage; ELBW, extreme low-birth weight infants. that rates of bronchopulmonary dysplasia and retinopathy of prematurity were significantly lower at the Neonatal Regional Tertiary Care Center, University of Vienna, compared with the Vermont Oxford Neonatal Network during the period 1994-2002, and this was attributed to more use of nasal CPAP and less use of mechanical ventilation during early respiratory management of VLBW infants. ${ }^{85}$

Improved respiratory outcomes for ELBW infants treated with a predominantly nasal CPAP approach were evident at Middlemore Hospital, New Zealand, compared with the Australian and New Zealand Neonatal Network data over a 3-year period (1998-2001). These infants spent a longer time on nasal CPAP and had less time on oxygen. Fewer of the Middlemore cohort were on oxygen at both 28 days, and 36 weeks corrected gestation, and fewer infants were discharged home on oxygen. ${ }^{86}$ On comparing the resuscitation and ventilator techniques between two NICUs in Stockholm, Sweden and Boston, MA, a less aggressive approach with more nasal CPAP administration in the delivery room was used in Stockholm, which did not decrease the risk for bronchopulmonary dysplasia at 36 weeks; however, at 40 weeks, fewer infants were on oxygen support, and a strong association was found between site, mean airway pressure, and mechanical ventilation with bronchopulmonary dysplasia, indicating that CPAP could have a beneficial role in outcome ${ }^{87}$ In contrast with these findings, a recent study investigated whether the wide variation in frequency of bronchopulmonary dysplasia between Italian hospitals is due to differences in delivery room intubation rates in VLBW infants. Rates of bronchopulmonary dysplasia, delivery room intubation, and mechanical ventilation for $>24$ hours differed significantly between hospitals. It was demonstrated that delivery room intubation and brief ( $<24$ hours) mechanical ventilation did not increase the risk of bronchopulmonary dysplasia. ${ }^{88}$

Five studies have evaluated neurodevelopmental outcomes in ELBW and VLBW infants managed with early CPAP. ${ }^{51,89-92}$ Neurodevelopmental follow-up at 5 years of age in a cohort of ELBW infants treated mainly with nasal CPAP during the neonatal period in Denmark (the ETFOL study) showed similar proportions of adverse effects on the brain compared with those in published follow-up studies of preterm infants treated with mechanical ventilation. ${ }^{51}$ Massaro et al demonstrated that ELBW infants managed with early nasal CPAP have neurodevelopmental morbidity at 3-6 months corrected age comparable with that of the National Institute of Child Health and Human Development 
Neonatal Research Network cohort. ${ }^{89}$ Dahl and Kamper demonstrated that VLBW infants treated with a regimen of early nasal CPAP/minimal handling had a relatively low incidence of handicap and impairment, with nearly $90 \%$ attending ordinary schools and near-average performance in mathematics and reading/spelling, which was not significantly different from their siblings..$^{90}$ Wintermark et al demonstrated that early application of nasal CPAP and avoidance of mechanical ventilation in VLBW infants showed no adverse effects on neurodevelopment and growth, and a significantly higher developmental quotient was found in the nasal CPAP group at a corrected age of 18 months. ${ }^{91}$ Thomas et al demonstrated that ELBW infants receiving nasal CPAP had better Bayley Score of Infant Development Version II scores at a corrected gestational age of 18-22 months, and lower rates of bronchopulmonary dysplasia and death compared with those receiving mechanical ventilation at 24 hours of age and, after adjusting for acuity differences, the ventilatory strategy at 24 hours of age independently predicts the longterm neurodevelopmental outcome. ${ }^{92}$

\section{Randomized controlled trials}

Observational studies alone do not provide strong enough evidence to justify and promote new clinical practices. Early randomized controlled trials that evaluated the role of CPAP in preterm infants were done in the presurfactant era and included small numbers of cases. Two Cochrane reviews of these trials showed a reduction in mortality of preterm infants $>1500 \mathrm{~g}$ with nasal CPAP, no significant differences in bronchopulmonary dysplasia, and a greater benefit from early application. They concluded that these trials provided insufficient information to make recommendations for clinical practice and called for a large randomized controlled trial. ${ }^{93,94}$ Finer et al investigated the feasibility of randomizing ELBW infants $<28$ weeks' gestation to nasal CPAP/positive endexpiratory pressure or no nasal CPAP/positive end-expiratory pressure during resuscitation immediately after delivery, avoiding routine delivery room intubation for surfactant administration, and initiating nasal CPAP on admission to the neonatal unit. In the first group, nasal CPAP of $5 \mathrm{~cm}$ $\mathrm{H}_{2} \mathrm{O}$ or IPPV (if necessary) with peak inspiratory pressure of $15-25 \mathrm{~cm} \mathrm{H}_{2} \mathrm{O}$ was given, and in the second group, no nasal CPAP and no positive end-expiratory pressure during IPPV was used. Nasal CPAP/positive end-expiratory pressure in the delivery room did not affect the need for intubation at birth or during the subsequent week, although this preliminary study was underpowered for detecting such a difference. ${ }^{95}$
Recently, five large multicenter, randomized controlled trials of appropriate design have tested the hypothesis that not intubating preterm babies with respiratory distress syndrome soon after birth would have a positive effect on outcome 63-66,96 $^{6}$ (Table 3). These trials support the use of CPAP as a primary strategy in preterm babies with respiratory distress syndrome who are breathing spontaneously. This approach led to a reduction in the number of infants intubated and given surfactant. On the other hand, half of the infants enrolled in these studies failed CPAP treatment. It can be argued that such babies might have been disadvantaged because of the delay in receiving surfactant therapy. As far as we know, no metaanalysis of the results of these studies has been done until now, and none of these studies evaluated neurodevelopmental outcomes in the infants who participated in this research. Unfortunately, two of these trials were not published in full and are available only in abstract form. ${ }^{63,96}$

The strategy of early nasal CPAP in VLBW infants may be justified based on the current clinical evidence, because it has been shown to be safe, and reduces the need for mechanical ventilation. ${ }^{95}$ However, to rely on nasal CPAP and "not to intubate" with the aim of reducing the incidence of bronchopulmonary dysplasia is not justified due to the low quality of evidence from retrospective/observational studies, ${ }^{72,73,75,76,79,80,83}$ and the lack of evidence from randomized controlled trials that not intubating in the delivery room reduces bronchopulmonary dysplasia..$^{63-66,96}$

Early nasal CPAP is not successful in all VLBW infants, and these infants will ultimately be ventilated mechanically. Forty-six percent of infants in the COIN (Continuous Positive Airway Pressure or Intubation at Birth) trial ${ }^{63}$ and $83 \%$ of infants in SUPPORT ${ }^{65}$ failed nasal CPAP. Ammari et al demonstrated that nasal CPAP was successful in $76 \%$ of infants with a birth weight of $\leq 1250 \mathrm{~g}$ and $50 \%$ of infants with a birth weight of $\leq 750 \mathrm{~g}$, and that nasal CPAP failure was associated with a need for positive pressure ventilation at delivery, alveolar-arterial oxygen tension gradient $>180 \mathrm{mmHg}$ on the first arterial blood gas, and severe respiratory distress syndrome on the initial chest $\mathrm{x}$-ray. ${ }^{97}$ Another study reported a delivery room nasal CPAP failure rate of $51 \%$ in preterm infants (26-27 weeks). Medical history and initial blood gas values were poor predictors of subsequent nasal CPAP failure. Moreover, it was found that a threshold fraction of inspired oxygen $\left(\mathrm{FiO}_{2}\right)$ of $\geq 0.35-0.45$ compared with $\geq 0.6$ for intubation would shorten the time to surfactant delivery without a relevant increase in intubation rate. ${ }^{98} \mathrm{~A}$ 
Table 3 Randomized controlled trials evaluating early NCPAP in preterm infants

\begin{tabular}{|c|c|c|c|}
\hline Study & Population & Comparison & Main results \\
\hline IFDAS trial ${ }^{63}$ & $\begin{array}{l}237 \text { infants } \\
(27-29 \text { weeks' gestation })\end{array}$ & $\begin{array}{l}\text { Early NCPAP with prophylactic surfactant } \\
\text { versus early NCPAP with rescue surfactant } \\
\text { versus early MV with prophylactic surfactant } \\
\text { versus early MV with rescue surfactant }\end{array}$ & $\begin{array}{l}\text { Less need for MV in the two NCPAP } \\
\text { groups during the first } 5 \text { days of life } \\
78 \% \text { of infants in groups I and } 2 \text { were } \\
\text { established on NCPAP by } \\
6 \text { hours of age } \\
\text { No significant differences among } \\
\text { the groups in mortality or oxygen } \\
\text { dependency (at either } 28 \text { days of life or } \\
\text { at } 36 \text { weeks' postmenstrual age) }\end{array}$ \\
\hline COIN trial ${ }^{64}$ & $\begin{array}{l}610 \text { infants } \\
(25-29 \text { weeks' gestation })\end{array}$ & NCPAP versus intubation with MV & $\begin{array}{l}\text { A } 50 \% \text { decrease in the use of surfactant } \\
\text { in NCPAP group } \\
\text { The NCPAP group also had fewer days } \\
\text { of MV } \\
\text { The combined outcome of death or } \\
\text { oxygen dependency at } 28 \text { days was lower } \\
\text { in the NCPAP group, but not significant at } \\
36 \text { weeks postmenstrual age } \\
\text { Greater incidence of pneumothorax in } \\
\text { NCPAP group ( } 9 \% \text { versus } 3 \% \text { ) }\end{array}$ \\
\hline SUPPORT trial ${ }^{65}$ & $\begin{array}{l}\text { I3 I6 infants } \\
(24-28 \text { weeks' gestation })\end{array}$ & $\begin{array}{l}\text { NCPAP at } 5 \mathrm{~cm} \mathrm{H}_{2} \mathrm{O} \text { in the delivery } \\
\text { room without any surfactant versus } \\
\text { intubation and surfactant treatment } \\
\text { within I hour after birth }\end{array}$ & $\begin{array}{l}\text { No difference in the primary outcome } \\
\text { of death or BPD } \\
\text { A high rate of intubation in the NCPAP } \\
\text { group ( } 83 \%) \\
\text { The NCPAP group had fewer days of MV } \\
\text { No difference in the occurrence of air leak } \\
\text { Less use of postnatal corticosteroids in } \\
\text { the NCPAP group }\end{array}$ \\
\hline VON trial ${ }^{66}$ & $\begin{array}{l}648 \text { infants } \\
(26-29 \text { weeks' gestation) }\end{array}$ & $\begin{array}{l}\text { Prophylactic surfactant followed by a } \\
\text { period of MV versus prophylactic surfactant } \\
\text { with rapid extubation to bubble NCPAP } \\
\text { versus initial management with bubble } \\
\text { NCPAP and selective surfactant } \\
\text { treatment if required }\end{array}$ & $\begin{array}{l}\text { The study was halted before the desired } \\
\text { sample size was reached because of } \\
\text { declining enrollment } \\
\text { No difference in the primary outcome of } \\
\text { combined death or BPD at } 36 \text { weeks } \\
\text { No difference in the incidence of } \\
\text { pneumothorax } \\
48 \% \text { of patients treated with NCPAP } \\
\text { were not intubated, and } 54 \% \text { did not } \\
\text { receive surfactant }\end{array}$ \\
\hline REVE trial ${ }^{96}$ & $\begin{array}{l}279 \text { infants } \\
(25-27 \text { weeks' gestation })\end{array}$ & $\begin{array}{l}\text { Early NCPAP after prophylactic surfactant } \\
\text { versus MV with prophylactic surfactant }\end{array}$ & $\begin{array}{l}\text { Intubation with early surfactant } \\
\text { administration followed by NCPAP } \\
\text { mostly benefits infants at } 25-26 \text { weeks' } \\
\text { gestation }\end{array}$ \\
\hline
\end{tabular}

Abbreviations: MV, mechanical ventilation; NCPAP, nasal continuous positive airway pressure; IFDAS, Infant Flow Driver and Surfactant; COIN, CPAP or Intubation trial; SUPPORT, Surfactant, Positive Pressure, and Pulse Oximetry Randomized Trial; VON, Vermont Oxford Network trial; REVE, REduction of VEntilation trial.

clinical prediction score for nasal CPAP failure in VLBW infants was developed recently. On multivariate analysis, the authors found three variables, ie, gestation $<28$ weeks, preterm premature rupture of membranes, and product of CPAP pressure and $\mathrm{FiO}_{2} \geq 1.28$ at initiation to maintain saturation between $88 \%$ and $93 \%$, to be independently predictive of failure. ${ }^{99}$ In another study, failure of the INSURE method was reported in $32 \%$ of preterm infants (23-28 weeks) receiving nasal CPAP. INSURE failure was significantly associated with the $\mathrm{PaCO}_{2}$ and mean arterial-to-alveolar oxygen tension ratio as well as a severe radiological grade in preterm infants with respiratory distress syndrome. ${ }^{100}$

Alternative methods of noninvasive respiratory support in VLBW infants include heated, humidified high-flow nasal cannulation, bilevel nasal CPAP, and nasal IPPV. Although the humidified high-flow nasal cannula has been widely used in many NICUs, ${ }^{101}$ there are scant data regarding its efficacy and safety. ${ }^{102}$ Bilevel nasal CPAP was associated with better respiratory outcomes versus nasal CPAP, and allowed 
earlier discharge in preterm infants with respiratory distress syndrome. ${ }^{103}$ Early use of nasal IPPV in preterm infants with respiratory distress syndrome reduced the need for intubation and mechanical ventilation, ${ }^{104}$ and reduced the risk of bronchopulmonary dysplasia ${ }^{105,106}$ compared with nasal CPAP. Although these findings are promising, further studies are needed to assess the potential benefits of these noninvasive ventilation techniques.

\section{Surfactant}

Surfactant therapy has been an excellent evidence-based measure of treatment for preterm respiratory distress syndrome since its introduction in 1990. In both VLBW ${ }^{107}$ and larger ${ }^{108-110}$ preterm infants, it has been shown to lead to a significant decrease in the risk of neonatal mortality and morbidity. ${ }^{111}$ Surfactant replacement therapy has decreased the incidence of pneumothorax and intraventricular hemorrhage, and improved survival of preterm infants. ${ }^{112}$

Recent developments in surfactant therapy for respiratory distress syndrome in preterm infants include comparative trials of natural versus synthetic surfactants, exploration of alternative modes of administration of surfactant, time of surfactant administration, and evaluation of the concomitant use of surfactant with short-term or noninvasive ventilation as adjuvant therapy.

\section{Natural versus synthetic surfactant}

Natural and synthetic surfactant preparations commonly used for neonatal respiratory distress syndrome are shown in Table 4. Natural surfactants are generally derived from either lung lavage or minced lung of bovine or porcine origin. Synthetic surfactants are complex combinations of dipalmitoylphosphatidylcholine and other phospholipids, neutral lipids, lipoprotein, or alcohols.

\section{Natural surfactant}

Individual trials have compared the efficacy and safety of various natural surfactants in the treatment of respiratory distress syndrome. Most reported differences in effectiveness between natural surfactant preparations were from short-term studies. Poractant alfa was found to have a more rapid onset of action than beractant in most studies. ${ }^{113-115}$ In a meta-analysis of five trials that compared poractant alfa with beractant in the treatment of preterm infants with respiratory distress syndrome, there was no difference in the primary outcome of bronchopulmonary dysplasia between the two different surfactant types $(31.5 \%$ versus $29.9 \%$, relative risk $0.98,95 \%$ confidence interval $0.75-1.29$ ), but a significant decrease in mortality rate was noted with the use of poractant versus beractant (relative risk 0.51, 95\% confidence interval 0.3-0.89). ${ }^{116}$ However, this difference in mortality was attributed to the use of higher doses of poractant alpha $(200 \mathrm{mg} / \mathrm{kg})$ compared with beractant $(100 \mathrm{mg} / \mathrm{kg})$ in three of the studies included in this meta-analysis. When the results were reproduced after exclusion of these trials, the difference in mortality was not statistically significant. ${ }^{117}$ Calfactant was found to have a more rapid effect with fewer doses, without having an effect on overall incidence of bronchopulmonary dysplasia or mortality when compared with beractant. ${ }^{118,119}$ Consistent with previous reports, the use of bovine lipid extract surfactant was associated with a more rapid improvement in oxygenation, but no effect on short-term outcome when compared with beractant. ${ }^{120}$ On the basis of the currently available evidence, no preparation can

Table 4 Surfactant products for neonatal respiratory distress syndrome

\begin{tabular}{|c|c|c|c|c|}
\hline Surfactant & Type & Preparation & Origin & Composition \\
\hline Poractant alfa & Natural & Curosurf ${ }^{\circledR}$ & $\begin{array}{l}\text { Porcine lung minces, lipid extraction with } \\
\text { purification using liquid-gel chromatography }\end{array}$ & $\mathrm{DPPC}+\mathrm{PG}+\mathrm{SP}-\mathrm{B}+\mathrm{SP}-\mathrm{C}$ \\
\hline Calfactant & Natural & Infasurf ${ }^{\circledR}$ & Calf lung lavage with lipid extraction & $\mathrm{DPPC}+\mathrm{PG}+\mathrm{SP}-\mathrm{B}+\mathrm{SP}-\mathrm{C}$ \\
\hline \multirow[t]{2}{*}{ Beractant } & Natural & Survanta ${ }^{\circledR}$ & $\begin{array}{l}\text { Bovine lung minces, lipid extraction, supplemented } \\
\text { with DPPC, palmitic acid and tripalmitin }\end{array}$ & $\mathrm{DPPC}+\mathrm{PG}+\mathrm{SP}-\mathrm{B}+\mathrm{SP}-\mathrm{C}$ \\
\hline & & Alveofact $^{\circledR}$ & Cow lung lavage fluid with lipid extraction & $\mathrm{DPPC}+\mathrm{PG}+\mathrm{SP}-\mathrm{B}+\mathrm{SP}-\mathrm{C}$ \\
\hline BLES & Natural & $\mathrm{BLES}^{\circledR}$ & Bovine lipid extract surfactant & $\mathrm{DPPC}+\mathrm{PG}+\mathrm{SP}-\mathrm{B}+\mathrm{SP}-\mathrm{C}$ \\
\hline Colfosceril & Synthetic & Exosurf ${ }^{\circledR}$ & $\begin{array}{l}\text { Synthetic DPPC in hexadecanol and tyloxapol } \\
\text { (as spreading agents) }\end{array}$ & DPPC \\
\hline Lucinactant & Synthetic & Surfaxin $^{\circledR}$ & Recombinant SP-B analog & $\begin{array}{l}\text { DPPC + POPG + palmitic acid + } \\
\text { recombinant SP-B analog }\end{array}$ \\
\hline Lusupultide & Synthetic & Venticute $^{\circledR}$ & Recombinant SP-C analog & $\begin{array}{l}\text { DPPC + PG + palmitic acid + } \\
\text { recombinant SP-C analog }\end{array}$ \\
\hline
\end{tabular}

Abbreviations: BLES, bovine lipid extract surfactant; DPPC, dipalmitoylphosphatidylcholine; PG, phosphatidylglycerol; POPG, palmitoyloleylphosphatidylglycerol; SP-B, surfactant protein B; SP-C, surfactant protein C. 
clearly be considered superior to another for the treatment of respiratory distress syndrome in preterm infants in terms of morbidity and mortality.

\section{Synthetic surfactant}

Although synthetic surfactants have theoretical advantages over natural surfactants, to date natural surfactants have been shown to be superior to synthetic surfactant in clinical trials due to the presence of protein B and C. ${ }^{124,125}$ The use of natural preparations was associated with lower inspired oxygen concentrations, ventilator pressures, mortality, and rates of respiratory distress syndrome complications in preterm infants. When used for treatment of respiratory distress syndrome, colfosceril was associated with slower weaning and more pneumothorax but no difference in major clinical outcomes compared with calfactant. When used for prophylaxis, calfactant was more effective than colfosceril in reducing the severity of respiratory distress syndrome and the number of associated deaths, but had no impact on overall mortality or bronchopulmonary dysplasia. ${ }^{124,125}$

New-generation synthetic surfactants containing peptides that mimic surfactant protein B (lucinactant) or surfactant protein $C$ (lusupultide) were developed to improve the efficacy of synthetic surfactants. Two large multicenter, randomized controlled trials compared the safety and efficacy of lucinactant with that of other surfactant preparations. The SELECT (Safety and Effectiveness of Lucinactant versus Exosurf in a Clinical Trial) study showed significant improvement in respiratory distress syndrome, related mortality through 14 days of life, and bronchopulmonary dysplasia when lucinactant was compared with colfosceril, as well as a reduction in total days on ventilation when compared with beractant. ${ }^{126}$ Similarly, the STAR (SURFAXIN ${ }^{\circledR}$ Therapy Against Respiratory distress syndrome) trial found that lucinactant was noninferior to poractant with regard to survival without bronchopulmonary dysplasia. Infants treated with lucinactant required significantly fewer doses compared with poractant. ${ }^{127}$ In summary, new-generation synthetic surfactant seems to have some advantages over previous synthetic surfactants containing only phospholipids, presumably because of the surfactant protein mimic, and is at least as good as currently used animal-derived surfactants.

\section{Mode of administration}

Intratracheal administration is presently the only approved means of delivering surfactant, due to its liquid nature. Accordingly, therapeutic use of surfactant is limited to infants who are intubated and/or undergoing mechanical ventilation. Furthermore, the process of surfactant administration requires a skilled attendant for endotracheal intubation. Tracheal intubation has potential risks, such as tracheal tube malpositioning or dislocation, hypoxia, bradycardia, and infection. Further, patients requiring tracheal intubation in an elective situation need to be treated with analgesic and sedative drugs that may have depressive respiratory effects. ${ }^{128}$

Alternative noninvasive techniques for administration of surfactant without tracheal intubation include administration through a laryngeal mask airway, nebulized surfactant, and minimally invasive surfactant therapy. Evidence for use of a laryngeal mask airway for surfactant administration comes from case reports and small uncontrolled trials. ${ }^{129,130}$ A Cochrane review, which included only one small trial, compared late rescue laryngeal mask airway surfactant with no treatment in preterm infants $\geq 1200$ g with respiratory distress syndrome, and administration of surfactant by a laryngeal mask airway was associated with no significant difference in need for subsequent mechanical ventilation and endotracheal surfactant, pneumothorax, days on IPPV, and days on IPPV or oxygen, but may have a short-term effect in reducing the requirement for oxygen. ${ }^{131}$

Administration of aerosolized surfactant has gained more interest because it is theoretically more gentle, noninvasive, and homogeneously distributed. Jorch et al demonstrated that CPAP and nebulized Alveofact ${ }^{\circledR}$ compared with CPAP alone resulted in an improved alveolar-arterial gradient and better $\mathrm{PaCO}_{2}$ levels in infants at 28-35 weeks' gestation. ${ }^{132}$ A comparison of nebulized Curosurf ${ }^{\circledR}$ and CPAP versus CPAP alone in infants at 23-36 weeks' gestation found no difference in clinical outcome, but demonstrated that nebulized surfactant was safe and well tolerated. ${ }^{133}$ Similarly, Finer et al showed the safety of nebulized lucinactant (Aerosurf ${ }^{\circledR}$ ) in 17 preterm infants at 28-32 weeks' gestation. ${ }^{134}$ However, issues regarding development of nebulizer devices capable of administration, effective administration, dosing strategies, and cost-effectiveness remain unresolved. ${ }^{135}$

Kribs et al described another technique of administering surfactant, known as the MIST (minimally invasive surfactant therapy) technique, whereby surfactant is administered via a thin endotracheal catheter during spontaneous breathing together with application of nasal CPAP. ${ }^{136}$ They reported that use of this technique increased between 2001 and 2004, and was associated with a significant increase in survival without bronchopulmonary dysplasia. ${ }^{136}$ A multicenter German study involving 1541 infants at $<31$ weeks' gestational age 
demonstrated a decreased need for mechanical ventilation during the first 72 hours and a lower rate of bronchopulmonary dysplasia and rate of death or bronchopulmonary dysplasia in infants treated with this new technique compared with those who received standard care. ${ }^{137}$ In a recent randomized controlled trial, preterm infants (26-28 weeks' gestation) randomized to this new technique required less mechanical ventilation and had fewer median days on mechanical ventilation compared with a standard treatment group. ${ }^{138}$ In another report, it was demonstrated that there was no significant difference regarding neurodevelopmental outcome in school-aged children treated after implementing this technique, even though surviving infants were more immature and survival rates had increased. ${ }^{139}$ Dargaville et al modified this technique using a 16-gauge vascular catheter inserted through the vocal cords under direct vision without the need for Magill forceps. ${ }^{140}$

The early use of noninvasive ventilation alone or in conjunction with surfactant may be as effective as intubation in preventing and treating respiratory distress syndrome in very premature infants. It has been suggested ${ }^{54}$ that the high survival rates and low incidence of bronchopulmonary dysplasia experienced in some centers in Scandinavia and the US were further improved when nasal CPAP was combined with early surfactant treatment and early extubation to nasal CPAP. ${ }^{128,141}$ The INSURE method, developed in Scandinavia, combines endotracheal intubation and surfactant application with early extubation to nasal CPAP. ${ }^{142}$ Infants are usually anesthetized with morphine, sometimes in combination with thiopental, followed by naloxone application to reverse respiratory depression. ${ }^{141,143}$

\section{Time of administration}

Surfactant administered within 2 hours of life to infants $\leq 28$ weeks' gestation reduced the incidences of pulmonary interstitial emphysema, bronchopulmonary dysplasia, pneumothorax, and mortality. ${ }^{144}$ Preterm infants with respiratory distress syndrome who received surfactant within 30 minutes of life showed reductions in pulmonary interstitial emphysema, death, intraventricular hemorrhage grade III-IV, and the combined outcome of bronchopulmonary dysplasia and death in comparison with infants who receive surfactant later on. ${ }^{145}$ However, most of the trials which studied the value of early versus late surfactant therapy were conducted before the era of routine antenatal steroids. ${ }^{146}$ Accordingly, the previously observed difference between early and delayed surfactant therapy may be smaller in current practice.
CURPAP, an international randomized controlled trial to evaluate the efficacy of combining prophylactic surfactant and early nasal continuous positive airway pressure in very preterm infants, reported no difference in need for mechanical ventilation, bronchopulmonary dysplasia, or pneumothorax among infants born at 24-28 weeks' gestation who were randomized to receive prophylactic or early selective surfactant with nasal CPAP, suggesting early rescue surfactant is as good as prophylactic surfactant. ${ }^{147}$ These results indicate that preterm infants (24-28 weeks' gestation) can be treated with nasal CPAP from birth, and that rescue INSURE should be used if nasal CPAP fails. In contrast, a multicenter study from Colombia randomized 279 preterm infants (27-31 weeks' gestation) with respiratory distress syndrome in the first hour of life to either an INSURE to CPAP protocol or to CPAP alone. The INSURE to CPAP group had lower mechanical ventilation requirements and less pneumothorax. No differences in rates of bronchopulmonary dysplasia or mortality were found. ${ }^{148}$ In a recent multicenter study from South America, 256 VLBW infants (800-1500 g) were randomized to a CPAP/INSURE group (if respiratory distress syndrome did not occur, CPAP was discontinued after 3-6 hours; if respiratory distress syndrome developed and the $\mathrm{FiO}_{2}$ was $>0.35$, the INSURE protocol was indicated) or to an oxygen/mechanical ventilation group (in the presence of respiratory distress syndrome, supplemental oxygen without CPAP was given, and if $\mathrm{FiO}_{2}$ was $>0.35$, surfactant and mechanical ventilation were provided). They demonstrated a reduced need for mechanical ventilation and less use of surfactant in the CPAP/INSURE group, and no differences in mortality, pneumothorax, bronchopulmonary dysplasia, and other complications of prematurity between the two groups. ${ }^{149}$

\section{Conclusion}

The lungs of preterm infants are vulnerable to injury, especially immediately after birth. Improvements in respiratory support for preterm infants in the delivery room have great potential to improve the short-term and long-term outcome. There is a need to avoid routine intubation of ELBW infants in the delivery room. New techniques for monitoring and critical assessment of postnatal adaptation are currently available and may help to improve decision-making during resuscitation. New synthetic preparations and noninvasive techniques for surfactant administration may prove to be better than conventional techniques. Further research is urgently required to assess the potential benefits of these interventions. 


\section{Disclosure}

The authors report no conflicts of interest in this work.

\section{References}

1. Costeloe K, Hennessy E, Gibson AT, Marlow N, Wilkinson AR. The EPICure study: outcomes to discharge from hospital for infants born at the threshold of viability. Pediatrics. 2000;106(4):659-671.

2. Markestad T, Kaaresen PI, Ronnestad A, et al. Early death, morbidity, and need of treatment among extremely premature infants. Pediatrics. 2005;115(5):1289-1298.

3. Tommiska V, Heinonen K, Lehtonen L, et al. No improvement in outcome of nationwide extremely low birth weight infant populations between 1996-1997 and 1999-2000. Pediatrics. 2007;119(1): 29-36.

4. Stoll BJ, Hansen NI, Bell EF, et al. Neonatal outcomes of extremely preterm infants from the NICHD Neonatal Research Network. Pediatrics. 2010;126(3):443-456.

5. Fanaroff AA, Stoll BJ, Wright LL, et al. Trends in neonatal morbidity and mortality for very low birthweight infants. Am J Obstet Gynecol. 2007;196(2):147. e1-e8.

6. Landmann E, Misselwitz B, Steiss JO, Gortner L. Mortality and morbidity of neonates born at $<26$ weeks of gestation (1998-2003). A population-based study. J Perinat Med. 2008;36(2):168-174.

7. Tyson JE, Parikh NA, Langer J, Green C, Higgins RD. Intensive care for extreme prematurity - moving beyond gestational age. $N \mathrm{Engl}$ J Med. 2008;358(16):1672-1681.

8. Vento M, Cheung PY, Aguar M. The first golden minutes of the extremely-low-gestational-age neonate: a gentle approach. Neonatology. 2009;95(4):286-298.

9. Fowlie PW, McGuire W. Immediate care of the preterm infant. BMJ. 2004;329(7470):845-848.

10. Langston C, Kida K, Reed M, Thurlbeck WM. Human lung growth in late gestation and in the neonate. Am Rev Respir Dis. 1984;129(4): 607-613.

11. Baraldi E, Filippone M. Chronic lung disease after premature birth. N Engl J Med. 2007;357(19):1946-1955.

12. Hallman M, Kulovich M, Kirkpatrick E, Sugarman RG, Gluck L. Phosphatidylinositol and phosphatidylglycerol in amniotic fluid: indices of lung maturity. Am J Obstet Gynecol. 1976;125(5):613-617.

13. O'Donovan DJ, Fernandes CJ. Free radicals and diseases in premature infants. Antioxid Redox Signal. 2004;6(1):169-176.

14. Hillman NH, Moss TJ, Kallapur SG, et al. Brief, large tidal volume ventilation initiates lung injury and a systemic response in fetal sheep. Am J Respir Crit Care Med. 2007;176(6):575-581.

15. Saugstad OD, Aune D. In search of the optimal oxygen saturation for extremely low birth weight infants: a systematic review and metaanalysis. Neonatology. 2011;100(1):1-8.

16. Saugstad OD, Ramji S, Soll RF, Vento M. Resuscitation of newborn infants with $21 \%$ or $100 \%$ oxygen: an updated systematic review and meta-analysis. Neonatology. 2008;94(3):176-182.

17. Rabi Y, Singhal N, Nettel-Aguirre A. Room-air versus oxygen administration for resuscitation of preterm infants: the ROAR study. Pediatrics. 2011;128(2):e374-e381.

18. Dawson JA, Kamlin CO, Wong C, et al. Oxygen saturation and heart rate during delivery room resuscitation of infants $<30$ weeks' gestation with air or $100 \%$ oxygen. Arch Dis Child Fetal Neonatal Ed. 2009; 94(2):F87-F91.

19. Escrig R, Arruza L, Izquierdo I, et al. Achievement of targeted saturation values in extremely low gestational age neonates resuscitated with low or high oxygen concentrations: a prospective, randomized trial. Pediatrics. 2008;121(5):875-881.

20. Vento M, Moro M, Escrig R, et al. Preterm resuscitation with low oxygen causes less oxidative stress, inflammation, and chronic lung disease. Pediatrics. 2009;124(3):e439-e449.
21. Kattwinkel J, Perlman JM, Aziz K, et al. Neonatal resuscitation: 2010 American Heart Association Guidelines for Cardiopulmonary Resuscitation and Emergency Cardiovascular Care. Pediatrics. 2010;126(5):e1400-e1413.

22. [No authors listed]. Supplemental Therapeutic Oxygen for Prethreshold Retinopathy Of Prematurity (STOP-ROP), a randomized, controlled trial. I: primary outcomes. Pediatrics. 2000;105(2):295-310.

23. Askie LM, Henderson-Smart DJ, Irwig L, Simpson JM. Oxygensaturation targets and outcomes in extremely preterm infants. $N$ Engl J Med. 2003;349(10):959-967.

24. Stenson B, Brocklehurst P, Tarnow-Mordi W. Increased 36-week survival with high oxygen saturation target in extremely preterm infants. N Engl J Med. 2011;364(17):1680-1682.

25. Carlo WA, Finer NN, Walsh MC, et al. Target ranges of oxygen saturation in extremely preterm infants. $N$ Engl J Med. 2010;362(21): 1959-1969.

26. Dawson JA, Kamlin CO, Wong C, et al. Changes in heart rate in the first minutes after birth. Arch Dis Child Fetal Neonatal Ed. 2010;95(3): F177-F181.

27. Dawson JA, Kamlin CO, Vento M, et al. Defining the reference range for oxygen saturation for infants after birth. Pediatrics. 2010;125(6): e1340-e1347.

28. Vento M, Aguar M, Brugada M, et al. Oxygen saturation targets for preterm infants in the delivery room. J Matern Fetal Neonatal Med. 2012;25 Suppl 1:45-46.

29. Dreyfuss D, Saumon G. Ventilator-induced lung injury: lessons from experimental studies. Am J Respir Crit Care Med. 1998;157(1): 294-323.

30. Jobe AH, Ikegami M. Mechanisms initiating lung injury in the preterm. Early Hum Dev. 1998;53(1):81-94.

31. Auten RL, Vozzelli M, Clark RH. Volutrauma. What is it, and how do we avoid it? Clin Perinatol. 2001;28(3):505-515.

32. Bjorklund LJ, Ingimarsson J, Curstedt $\mathrm{T}$, et al. Manual ventilation with a few large breaths at birth compromises the therapeutic effect of subsequent surfactant replacement in immature lambs. Pediatr Res. 1997;42(3):348-355.

33. Hoskyns EW, Milner AD, Boon AW, Vyas H, Hopkin IE. Endotracheal resuscitation of preterm infants at birth. Arch Dis Child. 1987;62(7): 663-666.

34. Hird MF, Greenough A, Gamsu HR. Inflating pressures for effective resuscitation of preterm infants. Early Hum Dev. 1991;26(1):69-72.

35. Milner AD. Resuscitation at birth. Eur J Pediatr. 1998;157(7): 524-527.

36. Schmolzer GM, Morley CJ, Wong C, et al. Respiratory function monitor guidance of mask ventilation in the delivery room: a feasibility study. J Pediatr. 2012;160(3):377-381. e2.

37. Finer NN, Rich W, Craft A, Henderson C. Comparison of methods of bag and mask ventilation for neonatal resuscitation. Resuscitation. 2001;49(3):299-305.

38. Hawkes CP, Ryan CA, Dempsey EM. Comparison of the T-piece resuscitator with other neonatal manual ventilation devices: A qualitative review. Resuscitation. January 4, 2012. [Epub ahead of print.]

39. Hussey SG, Ryan CA, Murphy BP. Comparison of three manual ventilation devices using an intubated mannequin. Arch Dis Child Fetal Neonatal Ed. 2004;89(6):F490-F493.

40. Karlberg P, Cherry RB, Escardo F, Koch G. Respiratory studies in newborn infants. I. Apparatus and methods for studies of pulmonary ventilation and the mechanics of breathing. Principles of analysis in mechanics of breathing. Acta Paediatr. 1960;49:345-357.

41. te Pas AB, Siew M, Wallace MJ, et al. Effect of sustained inflation length on establishing functional residual capacity at birth in ventilated premature rabbits. Pediatr Res. 2009;66(3):295-300.

42. te Pas AB, Siew M, Wallace MJ, et al. Establishing functional residual capacity at birth: the effect of sustained inflation and positive endexpiratory pressure in a preterm rabbit model. Pediatr Res. 2009;65(5): $537-541$. 
43. Vyas H, Milner AD, Hopkin IE, Boon AW. Physiologic responses to prolonged and slow-rise inflation in the resuscitation of the asphyxiated newborn infant. J Pediatr. 1981;99(4):635-639.

44. Phillips B, Zideman D, Wyllie J, Richmond S, van Reempts P. European Resuscitation Council Guidelines 2000 for Newly Born Life Support. A statement from the Paediatric Life Support Working Group and approved by the Executive Committee of the European Resuscitation Council. Resuscitation. 2001;48(3):235-239.

45. Jevon P. Resuscitation Council (UK) Newborn Life Support Course. Pract Midwife. 2001;4(11):22-23.

46. Harling AE, Beresford MW, Vince GS, Bates M, Yoxall CW. Does sustained lung inflation at resuscitation reduce lung injury in the preterm infant? Arch Dis Child Fetal Neonatal Ed. 2005;90(5):F406-F410.

47. Lindner W, Hogel J, Pohlandt F. Sustained pressure-controlled inflation or intermittent mandatory ventilation in preterm infants in the delivery room? A randomized, controlled trial on initial respiratory support via nasopharyngeal tube. Acta Paediatr. 2005;94(3):303-309.

48. te Pas AB, Walther FJ. A randomized, controlled trial of delivery-room respiratory management in very preterm infants. Pediatrics. 2007; 120(2):322-329.

49. Lista G, Fontana P, Castoldi F, Cavigioli F, Dani C. Does sustained lung inflation at birth improve outcome of preterm infants at risk for respiratory distress syndrome? Neonatology. 2011;99(1):45-50.

50. Wiswell TE. Continuous positive airway pressure. In: Goldsmith JP, Karotkin EH, editors. Assisted Ventilation of the Neonate, 4th ed. Philadelphia, PA: Saunders; 2003.

51. Hansen BM, Hoff B, Greisen G, Mortensen EL. Early nasal continuous positive airway pressure in a cohort of the smallest infants in Denmark neurodevelopmental outcome at five years of age. Acta Paediatr. 2004 93(2):190-195.

52. Gregory GA, Kitterman JA, Phibbs RH, Tooley WH, Hamilton WK. Treatment of the idiopathic respiratory-distress syndrome with continuous positive airway pressure. $N$ Engl J Med. 1971;284(24):1333-1340.

53. Van Marter LJ, Allred EN, Pagano M, et al. Do clinical markers of barotrauma and oxygen toxicity explain interhospital variation in rates of chronic lung disease? The Neonatology Committee for the Developmental Network. Pediatrics. 2000;105(6):1194-1201.

54. Verder H. Nasal CPAP has become an indispensable part of the primary treatment of newborns with respiratory distress syndrome. Acta Paediatr. 2007;96(4):482-484.

55. Burch K, Rhine W, Baker R, et al. Implementing potentially better practices to reduce lung injury in neonates. Pediatrics. 2003;111(4 Pt 2): e432-e436.

56. Levesque BM, Kalish LA, LaPierre J, Welch M, Porter V. Impact of implementing 5 potentially better respiratory practices on neonatal outcomes and costs. Pediatrics. 2011;128(1):e218-e226.

57. Lachmann B, Grossmann G, Nilsson R, Robertson B. Lung mechanics during spontaneous ventilation in premature and fullterm rabbit neonates. Respir Physiol. 1979;38(3):283-302.

58. Jobe AH, Kramer BW, Moss TJ, Newnham JP, Ikegami M. Decreased indicators of lung injury with continuous positive expiratory pressure in preterm lambs. Pediatr Res. 2002;52(3):387-392.

59. Mulrooney N, Champion Z, Moss TJ, Nitsos I, Ikegami M, Jobe AH Surfactant and physiologic responses of preterm lambs to continuous positive airway pressure. Am J Respir Crit Care Med. 2005;171(5): 488-493.

60. Nold JL, Meyers PA, Worwa CT, et al. Decreased lung injury after surfactant in piglets treated with continuous positive airway pressure or synchronized intermittent mandatory ventilation. Neonatology. 2007; 92(1):19-25.

61. Thomson MA, Yoder BA, Winter VT, et al. Treatment of immature baboons for 28 days with early nasal continuous positive airway pressure. Am J Respir Crit Care Med. 2004;169(9):1054-1062.

62. Polglase GR, Hillman NH, Ball MK, et al. Lung and systemic inflammation in preterm lambs on continuous positive airway pressure or conventional ventilation. Pediatr Res. 2009;65(1):67-71.
63. Thomson MA. Early nasal continuous positive airways pressure (nCPAP) with prophylactic surfactant for neonates at risk of RDS. The IFDAS multi-centre randomised trial. Pediatr Res. 2002;51:379A.

64. Morley CJ, Davis PG, Doyle LW, Brion LP, Hascoet JM, Carlin JB.Nasal CPAP or intubation at birth for very preterm infants. $N$ Engl $J$ Med. 2008;358(7):700-708.

65. Finer NN, Carlo WA, Walsh MC, et al. Early CPAP versus surfactant in extremely preterm infants. $N$ Engl J Med. 2010;362(21):1970-1979.

66. Dunn MS, Kaempf J, de Klerk A, et al. Randomized trial comparing 3 approaches to the initial respiratory management of preterm neonates. Pediatrics. 2011;128(5):e1069-e1076.

67. Loeliger M, Inder T, Cain S, et al. Cerebral outcomes in a preterm baboon model of early versus delayed nasal continuous positive airway pressure. Pediatrics. 2006;118(4):1640-1653.

68. Rees SM, Loeliger MM, Munro KM, et al. Cerebellar development in a baboon model of preterm delivery: impact of specific ventilatory regimes. J Neuropathol Exp Neurol. 2009;68(6):605-615.

69. Verney C, Rees S, Biran V, Thompson M, Inder T, Gressens P. Neuronal damage in the preterm baboon: impact of the mode of ventilatory support. J Neuropathol Exp Neurol. 2010;69(5):473-482.

70. Jacobsen T, Gronvall J, Petersen S, Andersen GE. "Minitouch" treatment of very low-birth-weight infants. Acta Paediatr. 1993;82(11): 934-938.

71. Gittermann MK, Fusch C, Gittermann AR, Regazzoni BM, Moessinger AC. Early nasal continuous positive airway pressure treatment reduces the need for intubation in very low birth weight infants. Eur J Pediatr. 1997;156(5):384-388.

72. Lindner W, Vossbeck S, Hummler H, Pohlandt F. Delivery room management of extremely low birth weight infants: spontaneous breathing or intubation? Pediatrics. 1999;103(5 Pt 1):961-967.

73. De Klerk AM, De Klerk RK. Nasal continuous positive airway pressure and outcomes of preterm infants. J Paediatr Child Health. 2001;37(2): 161-167.

74. Narendran V, Donovan EF, Hoath SB, Akinbi HT, Steichen JJ, Jobe AH. Early bubble CPAP and outcomes in ELBW preterm infants. J Perinatol. 2003;23(3):195-199.

75. Aly H, Milner JD, Patel K, El-Mohandes AA. Does the experience with the use of nasal continuous positive airway pressure improve over time in extremely low birth weight infants? Pediatrics. 2004;114(3): $697-702$.

76. Aly H, Massaro AN, Patel K, El-Mohandes AA. Is it safer to intubate premature infants in the delivery room? Pediatrics. 2005;115(6): $1660-1665$.

77. Jegatheesan P, Keller RL, Hawgood S. Early variable-flow nasal continuous positive airway pressure in infants $\leq 1000$ grams at birth. J Perinatol. 2006;26(3):189-196.

78. Zecca E, de Luca D, Costa S, Marras M, de Turris P, Romagnoli C. Delivery room strategies and outcomes in preterm infants with gestational age 24-28 weeks. J Matern Fetal Neonatal Med. 2006;19(9): 569-574.

79. Geary C, Caskey M, Fonseca R, Malloy M. Decreased incidence of bronchopulmonary dysplasia after early management changes, including surfactant and nasal continuous positive airway pressure treatment at delivery, lowered oxygen saturation goals, and early amino acid administration: a historical cohort study. Pediatrics. 2008;121(1): 89-96.

80. Miksch RM, Armbrust S, Pahnke J, Fusch C. Outcome of very low birthweight infants after introducing a new standard regime with the early use of nasal CPAP. Eur J Pediatr. 2008;167(8):909-916.

81. te Pas AB, Spaans VM, Rijken M, Morley CJ, Walther FJ. Early nasal continuous positive airway pressure and low threshold for intubation in very preterm infants. Acta Paediatr. 2008;97(8):1049-1054.

82. Nowadzky T, Pantoja A, Britton JR. Bubble continuous positive airway pressure, a potentially better practice, reduces the use of mechanical ventilation among very low birth weight infants with respiratory distress syndrome. Pediatrics. 2009;123(6):1534-1540. 
83. Mulder EE, Lopriore E, Rijken M, Walther FJ, Te Pas AB. Changes in respiratory support of preterm infants in the last decade: are we improving? Neonatology. 2012;101(4):247-253.

84. Avery ME, Tooley WH, Keller JB, et al. Is chronic lung disease in low birth weight infants preventable? A survey of eight centers. Pediatrics. 1987;79(1):26-30.

85. Kirchner L, Weninger M, Unterasinger L, et al. Is the use of early nasal CPAP associated with lower rates of chronic lung disease and retinopathy of prematurity? Nine years of experience with the Vermont Oxford Neonatal Network. J Perinat Med. 2005;33(1):60-66.

86. Meyer M, Mildenhall L, Wong M. Outcomes for infants weighing less than 1000 grams cared for with a nasal continuous positive airway pressure-based strategy. J Paediatr Child Health. 2004;40(1-2):38-41.

87. Vanpee M, Walfridsson-Schultz U, Katz-Salamon M, Zupancic JA, Pursley D, Jonsson B. Resuscitation and ventilation strategies for extremely preterm infants: a comparison study between two neonatal centers in Boston and Stockholm. Acta Paediatr. 2007;96(1): $10-16$.

88. Gagliardi L, Bellu R, Lista G, Zanini R. Do differences in delivery room intubation explain different rates of bronchopulmonary dysplasia between hospitals? Arch Dis Child Fetal Neonatal Ed. 2011;96(1): F30-F35.

89. Massaro AN, Glass P, Aly H. A report on early neurodevelopmental outcomes in extremely low birth weight infants managed on early nasal continuous positive airway pressure. J Pediatr Neurol. 2004;2(3): 149-152.

90. Dahl M, Kamper J. Physical outcome and school performance of very-low-birthweight infants treated with minimal handling and early nasal CPAP. Acta Paediatr. 2006;95(9):1099-1103.

91. Wintermark P, Tolsa JF, Van Melle G, Forcada-Guex M, Moessinger AC. Long-term outcome of preterm infants treated with nasal continuous positive airway pressure. Eur J Pediatr. 2007;166(5):473-483.

92. Thomas CW, Meinzen-Derr J, Hoath SB, Narendran V. Neurodevelopmental outcomes of extremely low birth weight infants ventilated with continuous positive airway pressure vs mechanical ventilation. Indian J Pediatr. 2012;79(2):218-223.

93. Ho JJ, Subramaniam P, Henderson-Smart DJ, Davis PG. Continuous distending pressure for respiratory distress syndrome in preterm infants. Cochrane Database Syst Rev. 2002;2:CD002271.

94. Ho JJ, Henderson-Smart DJ, Davis PG. Early versus delayed initiation of continuous distending pressure for respiratory distress syndrome in preterm infants. Cochrane Database Syst Rev. 2002;2:CD002975.

95. Finer NN, Carlo WA, Duara S, et al. Delivery room continuous positive airway pressure/positive end-expiratory pressure in extremely low birth weight infants: a feasibility trial. Pediatrics. 2004;114(3): 651-657.

96. Truffert P, Storme L, Fily A. Randomised trial comparing nasal CPAP versus conventional ventilation in extremely preterm infants. In: Progrès en Nèonatologie 38ème Journèes Nationales de Nèonatologie, Sociètè Française de Nèonatologie Ed. 2008:377-383. [French].

97. Ammari A, Suri M, Milisavljevic V, et al. Variables associated with the early failure of nasal CPAP in very low birth weight infants. J Pediatr. 2005;147(3):341-347.

98. Fuchs H, Lindner W, Leiprecht A, Mendler MR, Hummler HD. Predictors of early nasal CPAP failure and effects of various intubation criteria on the rate of mechanical ventilation in preterm infants of $<29$ weeks gestational age. Arch Dis Child Fetal Neonatal Ed. 2011;96(5):F343-F347.

99. Pillai MS, Sankar MJ, Mani K, Agarwal R, Paul VK, Deorari AK. Clinical prediction score for nasal CPAP failure in pre-term VLBW neonates with early onset respiratory distress. J Trop Pediatr. 2011;57(4):274-279.

100. Cherif A, Hachani C, Khrouf N. Risk factors of the failure of surfactant treatment by transient intubation during nasal continuous positive airway pressure in preterm infants. Am J Perinatol. 2008;25(10): $647-652$.
101. Dani C, Pratesi S, Migliori C, Bertini G. High flow nasal cannula therapy as respiratory support in the preterm infant. Pediatr Pulmonol. 2009;44(7):629-634.

102. Wilkinson D, Andersen C, O’Donnell CP, De Paoli AG. High flow nasal cannula for respiratory support in preterm infants. Cochrane Database Syst Rev. 2011;5:CD006405.

103. Lista G, Castoldi F, Fontana P, et al. Nasal continuous positive airway pressure (CPAP) versus bi-level nasal CPAP in preterm babies with respiratory distress syndrome: a randomised control trial. Arch Dis Child Fetal Neonatal Ed. 2010;95(2):F85-F89.

104. Sai Sunil Kishore M, Dutta S, Kumar P. Early nasal intermittent positive pressure ventilation versus continuous positive airway pressure for respiratory distress syndrome. Acta Paediatr. 2009;98(9): 1412-1415.

105. Kugelman A, Feferkorn I, Riskin A, Chistyakov I, Kaufman B, Bader D. Nasal intermittent mandatory ventilation versus nasal continuous positive airway pressure for respiratory distress syndrome: a randomized, controlled, prospective study. J Pediatr. 2007;150(5):521-526.

106. Bhandari V, Finer NN, Ehrenkranz RA, et al. Synchronized nasal intermittent positive-pressure ventilation and neonatal outcomes. Pediatrics. 2009;124(2):517-526.

107. Henderson-Smart DJ, Osborn D, Evans N, Beeby P, Jeffery H. Do we practice evidence-based care in our neonatal intensive care units? Clin Perinatol. 2003;30(2):333-342.

108. Long W, Corbet A, Cotton R, et al. A controlled trial of synthetic surfactant in infants weighing $1250 \mathrm{~g}$ or more with respiratory distress syndrome. The American Exosurf Neonatal Study Group I, and the Canadian Exosurf Neonatal Study Group. N Engl J Med. 1991; 325(24):1696-1703.

109. Escobedo MB, Gunkel JH, Kennedy KA, et al. Early surfactant for neonates with mild to moderate respiratory distress syndrome: a multicenter, randomized trial. J Pediatr. 2004;144(6):804-808.

110. Dunn MS, Shennan AT, Possmayer F. Single- versus multiple-dose surfactant replacement therapy in neonates of 30 to 36 weeks' gestation with respiratory distress syndrome. Pediatrics. 1990;86(4): 564-571.

111. Soll RF. Synthetic surfactant for respiratory distress syndrome in preterm infants. Cochrane Database Syst Rev. 2000;2:CD001149.

112. Stevens TP, Sinkin RA. Surfactant replacement therapy. Chest. 2007;131(5):1577-1582.

113. Malloy CA, Nicoski P, Muraskas JK. A randomized trial comparing beractant and poractant treatment in neonatal respiratory distress syndrome. Acta Paediatr. 2005;94(6):779-784.

114. Ramanathan R, Rasmussen MR, Gerstmann DR, Finer N, Sekar K. A randomized, multicenter masked comparison trial of poractant alfa (Curosurf) versus beractant (Survanta) in the treatment of respiratory distress syndrome in preterm infants. Am J Perinatol. 2004;21(3): 109-119.

115. Speer CP, Gefeller O, Groneck P, et al. Randomised clinical trial of two treatment regimens of natural surfactant preparations in neonatal respiratory distress syndrome. Arch Dis Child Fetal Neonatal Ed. 1995;72(1):F8-F13.

116. Singh N, Hawley KL, Viswanathan K. Efficacy of porcine versus bovine surfactants for preterm newborns with respiratory distress syndrome: systematic review and meta-analysis. Pediatrics. 2011; 128(6):e1588-e1595.

117. Halliday HL. History of surfactant from 1980. Biol Neonate. 2005; 87(4):317-322.

118. Attar MA, Becker MA, Dechert RE, Donn SM. Immediate changes in lung compliance following natural surfactant administration in premature infants with respiratory distress syndrome: a controlled trial. J Perinatol. 2004;24(10):626-630.

119. Bloom BT, Kattwinkel J, Hall RT, et al. Comparison of Infasurf (calf lung surfactant extract) to Survanta (Beractant) in the treatment and prevention of respiratory distress syndrome. Pediatrics. 1997;100(1): 31-38. 
120. Lam BC, Ng YK, Wong KY. Randomized trial comparing two natural surfactants (Survanta vs BLES) for treatment of neonatal respiratory distress syndrome. Pediatr Pulmonol. 2005;39(1):64-69.

121. Seger N, Soll R. Animal derived surfactant extract for treatment of respiratory distress syndrome. Cochrane Database Syst Rev. 2009;2: CD007836.

122. Engle WA. Surfactant-replacement therapy for respiratory distress in the preterm and term neonate. Pediatrics. 2008;121(2):419-432.

123. Sweet DG, Carnielli V, Greisen G, et al. European consensus guidelines on the management of neonatal respiratory distress syndrome in preterm infants - 2010 update. Neonatology. 2011;97(4):402-417.

124. Hudak ML, Farrell EE, Rosenberg AA, et al. A multicenter randomized, masked comparison trial of natural versus synthetic surfactant for the treatment of respiratory distress syndrome. J Pediatr. 1996;128(3):396-406.

125. Hudak ML, Martin DJ, Egan EA, et al. A multicenter randomized masked comparison trial of synthetic surfactant versus calf lung surfactant extract in the prevention of neonatal respiratory distress syndrome. Pediatrics. 1997;100(1):39-50.

126. Moya FR, Gadzinowski J, Bancalari E, et al. A multicenter, randomized, masked, comparison trial of lucinactant, colfosceril palmitate, and beractant for the prevention of respiratory distress syndrome among very preterm infants. Pediatrics. 2005;115(4):1018-1029.

127. Sinha SK, Lacaze-Masmonteil T, Valls I Soler A, et al. A multicenter, randomized, controlled trial of lucinactant versus poractant alfa among very premature infants at high risk for respiratory distress syndrome. Pediatrics. 2005;115(4):1030-1038.

128. Verder H, Albertsen P, Ebbesen F, et al. Nasal continuous positive airway pressure and early surfactant therapy for respiratory distress syndrome in newborns of less than 30 weeks' gestation. Pediatrics. 1999;103(2):E24.

129. Brimacombe J, Gandini D, Keller C. The laryngeal mask airway for administration of surfactant in two neonates with respiratory distress syndrome. Paediatr Anaesth. 2004;14(2):188-190.

130. Trevisanuto D, Grazzina N, Ferrarese P, Micaglio M, Verghese C, Zanardo V. Laryngeal mask airway used as a delivery conduit for the administration of surfactant to preterm infants with respiratory distress syndrome. Biol Neonate. 2005;87(4):217-220.

131. Abdel-Latif ME, Osborn DA. Laryngeal mask airway surfactant administration for prevention of morbidity and mortality in preterm infants with or at risk of respiratory distress syndrome. Cochrane Database Syst Rev. 2011;7:CD008309.

132. Jorch G, Hartl H, Roth B, et al. Surfactant aerosol treatment of respiratory distress syndrome in spontaneously breathing premature infants. Pediatr Pulmonol. 1997;24(3):222-224.

133. Berggren E, Liljedahl M, Winbladh B, et al. Pilot study of nebulized surfactant therapy for neonatal respiratory distress syndrome. Acta Paediatr. 2000;89(4):460-464.

134. Finer NN, Merritt TA, Bernstein G, Job L, Mazela J, Segal R. An open label, pilot study of Aerosurf ${ }^{\text {ह }}$ combined with nCPAP to prevent RDS in preterm neonates. J Aerosol Med Pulm Drug Deliv. 2010; 23(5):303-309
135. Shah S. Exogenous surfactant: intubated present, nebulized future? World J Pediatr. 2011;7(1):11-15.

136. Kribs A, Vierzig A, Hunseler C, et al. Early surfactant in spontaneously breathing with nCPAP in ELBW infants - a single centre four year experience. Acta Paediatr. 2008;97(3):293-298.

137. Kribs A, Hartel C, Kattner E, et al. Surfactant without intubation in preterm infants with respiratory distress: first multi-center data. Klin Padiatr. 2010;222(1):13-17. German.

138. Gopel W, Kribs A, Ziegler A, et al. Avoidance of mechanical ventilation by surfactant treatment of spontaneously breathing preterm infants (AMV): an open-label, randomised, controlled trial. Lancet. 2011;378(9803):1627-1634.

139. Porath M, Korp L, Wendrich D, Dlugay V, Roth B, Kribs A. Surfactant in spontaneous breathing with nCPAP: neurodevelopmental outcome at early school age of infants $\leq 27$ weeks. Acta Paediatr. 2011;100(3) 352-359.

140. Dargaville PA, Aiyappan A, Cornelius A, Williams C, De Paoli AG. Preliminary evaluation of a new technique of minimally invasive surfactant therapy. Arch Dis Child Fetal Neonatal Ed. 2011;96(4) F243-F248.

141. Verder H, Robertson B, Greisen G, et al. Surfactant therapy and nasal continuous positive airway pressure for newborns with respiratory distress syndrome. Danish-Swedish Multicenter Study Group. NEngl J Med. 1994;331(16):1051-1055.

142. Blennow M, Jonsson B, Dahlstrom A, Sarman I, Bohlin K, Robertson B. Lung function in premature infants can be improved. Surfactant therapy and CPAP reduce the need of respiratory support. Lakartidningen. 1999;96(13):1571-1576. Swedish.

143. Bohlin K, Gudmundsdottir T, Katz-Salamon M, Jonsson B, Blennow M. Implementation of surfactant treatment during continuous positive airway pressure. J Perinatol. 2007;27(7):422-427.

144. Yost CC, Soll RF. Early versus delayed selective surfactant treatment for neonatal respiratory distress syndrome. Cochrane Database Syst Rev. 2000;2:CD001456

145. Soll RF, Blanco F. Natural surfactant extract versus synthetic surfactant for neonatal respiratory distress syndrome. Cochrane Database Syst Rev. 2001;2:CD000144

146. Horbar JD, Carpenter JH, Buzas J, et al. Timing of initial surfactant treatment for infants 23 to 29 weeks' gestation: is routine practice evidence based? Pediatrics. 2004;113(6):1593-1602.

147. Sandri F, Plavka R, Simeoni U. The CURPAP study: an international randomized controlled trial to evaluate the efficacy of combining prophylactic surfactant and early nasal continuous positive airway pressure in very preterm infants. Neonatology. 2008;94(1):60-62.

148. Rojas MA, Lozano JM, Rojas MX, et al. Very early surfactant without mandatory ventilation in premature infants treated with early continuous positive airway pressure: a randomized, controlled trial. Pediatrics. 2009;123(1):137-142.

149. Tapia JL, Urzua S, Bancalari A, et al. Randomized trial of early bubble continuous positive airway pressure for very low birth weight infants. $J$ Pediatr. March 6, 2012. [Epub ahead of print.]

Research and Reports in Neonatology

\section{Publish your work in this journal}

Research and Reports in Neonatology is an international, peer-reviewed, open access journal publishing original research, reports, editorials, reviews and commentaries on neonatal health. The manuscript management system is completely online and includes a very quick and fair

peer-review system. Visit http://www.dovepress.com/testimonials.php to read real quotes from published authors. 